\title{
Patulin Inhibition of Mycovirus Replication in Penicillium stoloniferum*
}

\author{
By R. W. DETROY AND P. E. STILL \\ Northern Regional Research Laboratory, \\ Agricultural Research Service, U.S. Department of Agriculture, \\ Peoria, Illinois 61604, U.S.A.
}

(Received 13 June 1975)

\section{SUMMARY}

Penicillium stoloniferum NRRL5267 contains two electrophoretically distinct viruses (PsV-F and PsV-S). An in vivo system was developed to test whether a number of fungal metabolites had antiviral properties on PsV-F replication in $P$. stoloniferum. Preliminary results indicated that the mycotoxin patulin can block mycovirus replication. Portions of $48 \mathrm{~h}$ mycelium were incubated in the presence of varying levels of patulin, and after an additional $48 \mathrm{~h}$ incubation, PsV-F content was measured in $E_{260}$ units by polyacrylamide gel electrophoresis. Patulin at I I, I6 and $20 \mu \mathrm{g} / \mathrm{mg}$ dry wt mycelia blocked PsV-F replication 26, 6I and 7I \%, respectively, compared with untreated controls. At these levels, host biomass RNA and protein synthesis were minimally affected. Non-proliferating fungal mycelium is capable of continued support of PsV-F replication, which is sensitive to patulin. Apparently, inhibitory doses of patulin stimulated PsV-S replication during this $48 \mathrm{~h}$ incubation. The preferential action of patulin may arise from metabolite binding to functional enzymes required for virus replication.

\section{INTRODUCTION}

Although mycoviruses have been isolated from a number of economically and industrially important fungi, such as Ustilago maydis, Helminthosporium maydis, Penicillium chrysogenum and Aspergillus niger (Bozarth, 1972; Lemke \& Nash, 1974), evidence is limited concerning the regulatory function fungal metabolites may exert in controlling virus replication and, eventually, survival of a virus in a fungal species.

Several strains of Penicillium stoloniferum and Penicillium brevi-compactum synthesize mycophenolic acid, an antiviral fungal metabolite (Birkinshaw, Bracken \& Morgan, 1948). Detroy, Freer \& Fennell (1973) observed that $P$. stoloniferum strain NRRL5267 contains a high titre of mycovirus but produces no mycophenolic acid, whereas all other strains produce mycophenolic acid and contain no mycovirus. All $\boldsymbol{P}$. brevi-compactum isolates examined produced mycophenolic acid, and only one strain had a low level of virus. Learning how mycophenolic acid may control virus replication depends upon developing adequate techniques for virus transmission to non-infected fungal strains.

Penicillium stoloniferum Thom NRRL5267 (ATCCI4586) contains two electrophoretically and serologically distinct viruses (PsV-F and PsV-S). The virus with the highest electrophoretic mobility (PsV-F) contains three distinct classes of double-stranded RNA (dsRNA), whereas PsV-S contains two dsRNA classes according to Bozarth, Wood \& Mandelbrot

* A report of this work was presented at the American Society for Microbiology meeting, New York, New York, 27 April-2 May 1975. 
(1971). Their initial studies indicate that the level of PsV-F to PsV-S is tenfold greater in $P$. stoloniferum cells grown on a corn steep medium for 3 days.

An in vivo replication system from $P$. stoloniferum NRRL5267 has been developed to test various fungal metabolites for antiviral activity against $P$. stoloniferum (PsV-F) replication (Detroy \& Still, I975). We have continued our studies with the two mycoviruses of $P$. stoloniferum while evaluating the antifungal and antiviral properties of the mycotoxin patulin.

Patulin, a fungal toxin produced by several species of Aspergillus and Penicillium (Abraham \& Florey, 1949), contains the $\alpha, \beta$-unsaturated lactone structure. This toxin has antibiotic activity, is toxic to animals (Hooper et al. 1944; Norstadt \& McCalla, 1968) and is carcinogenic in rats and mice (Dickens \& Jones, I96I, 1965). As for mode of action, Jones \& Young (1968) suggested that the SH group of thiol enzymes reacts with the double bond conjugated to the lactone carbonyl group of patulin, and Atkinson \& Stanley (1943) suggested that the antibiotic activity of patulin may be due to its reaction with SH groups of microbial enzymes. Ashoor \& Chu (1973) showed that patulin inhibits yeast alcohol dehydrogenase $(\mathrm{ADH})$ and rabbit-muscle lactic dehydrogenase activities in vitro.

Information is presented on the interaction of patulin with mycovirus replication and host metabolism in $P$. stoloniferum.

\section{METHODS}

Organisms and growth conditions. The virus-containing strain of $P$. stoloniferum NRRL5267 was supplied by the U.S. Agricultural Research Service Culture Collection maintained at the Northern Regional Research Laboratory, Peoria, Illinois, U.S.A. During our investigations, the organism was maintained on potato dextrose agar (PDA) slants. Conidia $\left(10^{6}\right.$ to $\left.10^{7}\right)$ in $0.01 \%$ Triton-X were used to inoculate each $500 \mathrm{ml}$ Erlenmeyer flask containing $100 \mathrm{ml}$ of $2 \%(\mathrm{w} / \mathrm{v})$ yeast extract - $15 \%(\mathrm{w} / \mathrm{v})$ sucrose (YES) medium. Incubation was at $28{ }^{\circ} \mathrm{C}$ on a Brunswick rotary shaker at $250 \mathrm{rev}$./min for $48 \mathrm{~h}$.

Measurement of fungal growth. To sterile $50 \mathrm{ml}$ Erlenmeyer flasks were transferred $20 \mathrm{ml}$ of the $48 \mathrm{~h}$ mycelia for an additional $48 \mathrm{~h}$ incubation in the presence of various levels of patulin and $\left[{ }^{14} \mathrm{C}\right]$ nucleic acid and protein precursors. Dry weight biomass was measured after washing the mycelium by filtration with distilled water and drying for $2 \mathrm{~h}$ at $75^{\circ} \mathrm{C}$. In the in vivo test used to follow host protein and RNA synthesis, mycelium was incubated for an additional $48 \mathrm{~h}$ in the presence of $5 \mu \mathrm{Ci}$ of ${ }^{2-}-\left[{ }^{14} \mathrm{C}\right]$ uracil or $\left[{ }^{14} \mathrm{C}\right]$ leucine, with or without added patulin. Flasks were removed at intervals, mycelium was disrupted in a Bronwill mechanical cell homogenizer, and portions of the cell-free supernatants were treated with equal volumes of cold $10 \%(w / v)$ trichloroacetic acid for $15 \mathrm{~min}$. The precipitates were filtered on glass fibre discs, washed with cold $5 \%(w / v)$ trichloroacetic acid, dried and placed into a scintillation vial to determine readioactivity.

Determination of patulin. To estimate patulin uptake by the fungal mycelium, both spent media and cell-free supernatants were chloroform-extracted and the patulin concentration was estimated from thin-layer chromatographic plates containing a $254 \mathrm{~nm}$ fluorescent indicator (Wilson, 1975).

Estimation of virus. To estimate PsV-F particles at $\mathrm{I} 2 \mathrm{~h}$ intervals, from 0.8 to $\mathrm{I} \cdot 5 \mathrm{~g}$ wet wt mycelium was transferred to a $75 \mathrm{ml}$ glass Bronwill homogenizer flask, and cells were disrupted in $0 . \mathrm{I} \mathrm{M}$-phosphate buffer $\mathrm{pH} 7.2$ and virus was concentrated by ultracentrifugation (Detroy \& Still, 1975). The method is shown in Fig. I. 


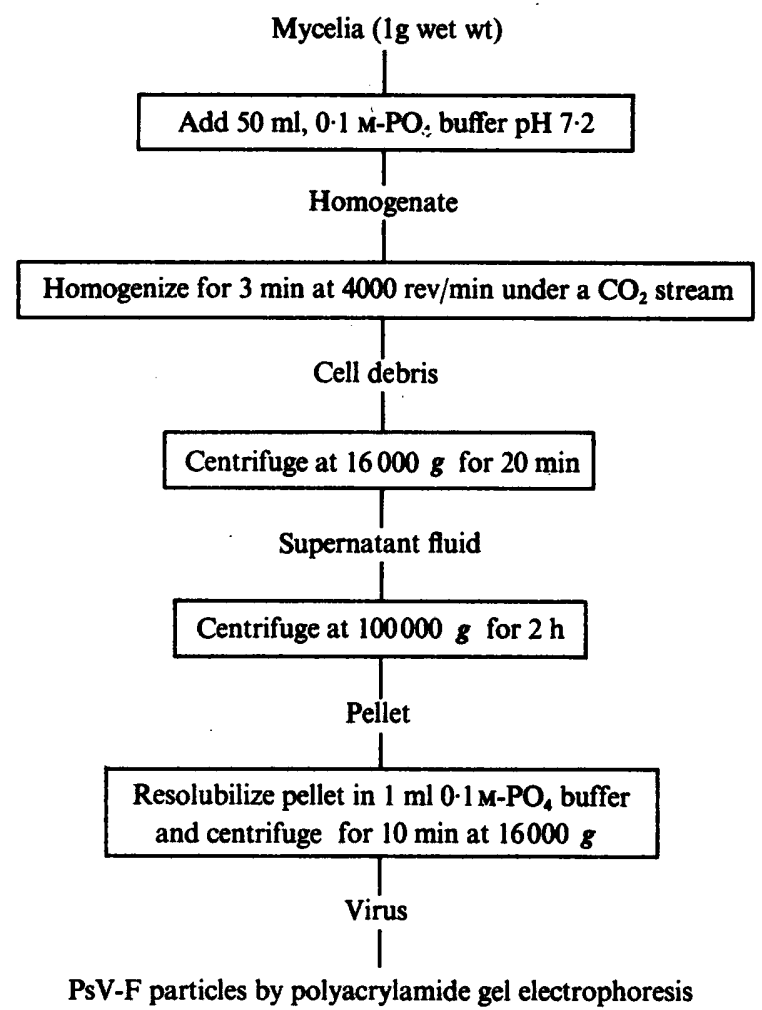

Fig. I. Protocol for isolating and estimating PsV-F particles in mycelia of $P$. stoloniferum NRRL5267.

$P s V-F$ replication in a resting-cell system. The $48 \mathrm{~h}$ mycelium, grown as described earlier, was washed with sterile water on a Buchner funnel and resuspended in sterile water at a concentration equivalent to that of the cells in YES medium at $48 \mathrm{~h}$. Portions $(20 \mathrm{ml})$ of the resuspended $48 \mathrm{~h}$ mycelium were transferred to $55 \mathrm{ml}$ distilled water in $300 \mathrm{ml}$ Erlenmeyer flasks. Mycelium was harvested after an additional 24 or $48 \mathrm{~h}$ incubation at $28^{\circ} \mathrm{C}$ on a rotary shaker and analysed for fungal biomass and PsV-F content.

Polyacrylamide gels $(2.4 \%$, w/v, acrylamide, $0.15 \%$ bisacrylamide and $0.5 \%$ agarose in TAE-SDS buffer, consisting of $0.09 \mathrm{M}$-tris, $0.07 \mathrm{M}$-sodium acetate, $0.002 \mathrm{M}$-EDTA and $0.5 \%$, w/w, SDS, $\mathrm{pH} 7$ ) were prepared essentially as described by Loening (1967). Electrophoresis was carried out for $2.5 \mathrm{~h}$ at $6.5 \mathrm{~mA}$ per tube at $25^{\circ} \mathrm{C}$. Gels were scanned at $260 \mathrm{~nm}$ by a Gilford linear transport system.

A PsV-F standard, with $10 E_{260}$ units (extinction units at $260 \mathrm{~nm}$ in a $1 \mathrm{~cm}$ cell) per millilitre, was prepared by sucrose gradient centrifugation and analysed by gel electrophoresis for purity. A PsV-F standard curve was determined because the area under the PsV-F peak showed a linear relationship to amounts of PsV-F (0.03 and $0.25 E_{260}$ units) applied to the gels. Quantities of virus in mycelial homogenates were estimated by comparing the area under the PsV-F peaks to known $E_{260}$ units of standard PsV-F.

A typical profile is depicted in Fig. 2 of PsV-F and PsV-F from $P$. stoloniferum $72 \mathrm{~h}$ mycelium. 


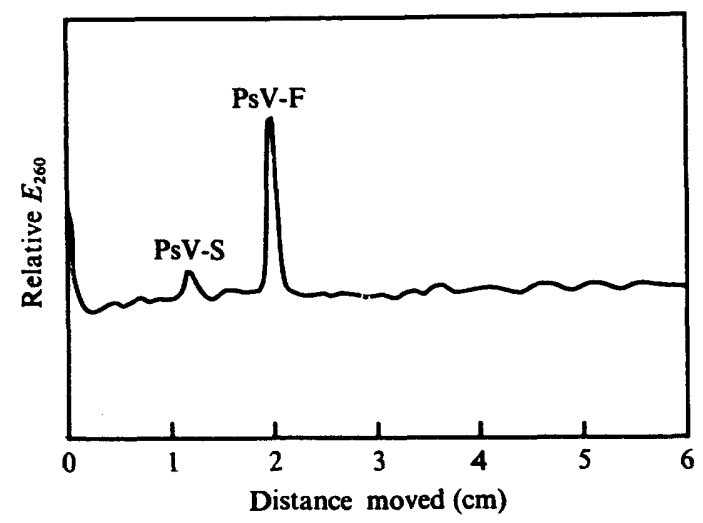

Fig. 2. Electrophoretogram of PsV-S and PsV-F from $P$. stoloniferum. The $2.4 \%$ gels were run at $6.5 \mathrm{~mA} /$ tube for $2.5 \mathrm{~h}$.

Table 1. Influence of patulin concentration upon PsV-F replication with varying amounts of mycelial biomass

\begin{tabular}{lrrrrr} 
& \multicolumn{5}{c}{ Dry wt biomass* $(\mathrm{mg} / 20 \mathrm{ml})$} \\
\cline { 2 - 6 } & 100 & 125 & 180 & 200 & 250 \\
Patulin $\dagger(\mu \mathrm{g} / \mathrm{ml})$ & 100 & 100 & 100 & 100 & 100 \\
Inhibition PsV-F $\ddagger(\%)$ & 71 & 67 & 78 & 20 & 0
\end{tabular}

* Depicts zero time biomass levels for several experiments. Cells incubated in YES (20 ml) for $48 \mathrm{~h}$ in either presence or absence of $100 \mu \mathrm{g}$ patulin $/ \mathrm{ml}$.

$\uparrow$ Patulin concentration represents $100 \mu \mathrm{g} / \mathrm{ml}$ in a $20 \mathrm{ml}$ mycelium volume.

$\ddagger$ Percentage inhibition was calculated by dividing the change in PsV-F level after a $48 \mathrm{~h}$ incubation by the change in controls and subtracting this number from roo.

Materials. $2-\left[{ }^{14} \mathrm{C}\right]$ uracil and ${ }^{14} \mathrm{C}$-leucine were supplied by International Chemical and Nuclear Corp., City of Industry, California, U.S.A., and patulin was prepared at the Northern Regional Research Laboratory.

\section{RESULTS}

Inhibition of fungal growth and PsV-F replication by patulin

Since preliminary observations indicated that patulin inhibited PsV-F replication, further studies were undertaken to determine its antifungal and antiviral properties. Apparently the degree of PsV-F inhibition does not depend upon the concentration of patulin because initially the inhibition of PsV-F replication varied substantially with patulin at $100 \mu \mathrm{g} / \mathrm{ml}$ (Table I). The degree of PsV-F replication inhibition apparently depends upon the ratio of patulin to the initial biomass of cells treated.

The quantitative effects of patulin upon fungal growth and PsV-F replication are given in Table 2. Patulin at $8 \mu \mathrm{g} / \mathrm{mg}$ dry wt or less was ineffective against fungal growth (biomass increase) and PsV-F replication. PsV-F replication at levels of II, I3 and $20 \mu \mathrm{g} / \mathrm{mg}$ was substantially blocked at 26,50 and $71 \%$, respectively, with minimal effect upon fungal growth. At higher levels of patulin, from 24 to $54 \mu \mathrm{g} / \mathrm{mg}$ fungal growth was inhibited from 5 to $100 \%$, and PsV-F synthesis was blocked from 73 to $100 \%$. At concentrations greater than $20 \mu \mathrm{g} / \mathrm{mg}$ dry wt, patulin no longer inhibited only PsV-F replication, but also inhibited growth of the fungal host. 
Table 2. Effect of patulin upon fungal growth and PsV-F replication

\begin{tabular}{lrrrrrrrrrrrrr}
\multicolumn{10}{c}{ Patulin concn $\dagger$} & \multicolumn{10}{c}{$(\mu \mathrm{g} / \mathrm{mg}$ dry $w \mathrm{t})$} \\
$\quad$ & $\begin{array}{l}\text { Percentage } \\
\text { inhibition* }\end{array}$ & 4 & 6 & 8 & 11 & 13 & 16 & 20 & 24 & 28 & 32 & 40 & 54 \\
Ps V-F content & 0 & 0 & 0 & 26 & 50 & 61 & 71 & 73 & 74 & 80 & 95 & 100 \\
Dry wt & 0 & 0 & 0 & 0 & 0 & 0 & 0 & 5 & 13 & 24 & 50 & 100
\end{tabular}

* Percentage inhibition of Ps V-F content was calculated by dividing the change in PsV-F level between 48 and $96 \mathrm{~h}$ in mycelium by the change in controls and subtracting this number from roo. Percentage inhibition of dry was calculated similarly.

$\dagger$ Patulin was added as from 0.1 to $1 \mathrm{ml}$ solutions to $20 \mathrm{ml}$ of $48 \mathrm{~h}$ mycelia of $P$. stoloniferum in YES medium to yield the appropriate patulin:mycelial dry weight ratios. Zero time dry weight was determined before patulin addition.
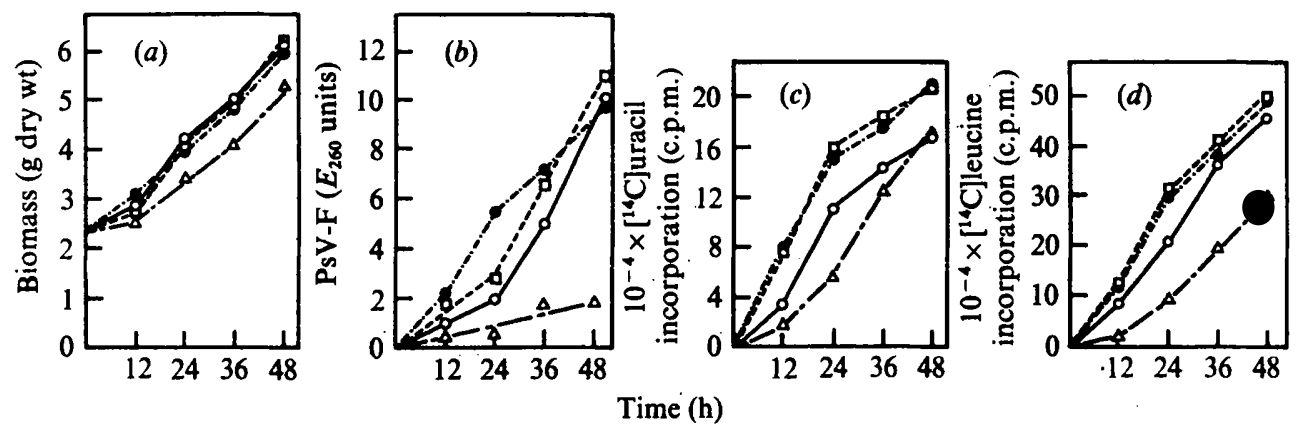

Fig. 3. Inhibition of biomass, protein, RNA and PsV-F synthesis in proliferating mycelium of $P$. stoloniferum by patulin. [ $\left.{ }^{14} \mathrm{C}\right]$ uracil and $\left[{ }^{11} \mathrm{C}\right]$ leucine were added to $20 \mathrm{ml}$ of $48 \mathrm{~h}$ mycelium at the same time as patulin addition. A series of control flasks not treated with patulin received similar

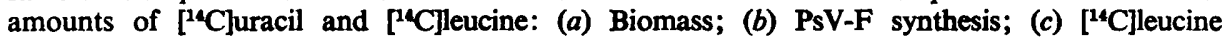
incorporation into protein; $(d){ }^{14} \mathrm{C}$ luracil incorporation into RNA. Patulin concentration $(\mu \mathrm{g} / \mathrm{mg}$ dry wt): 0,0 (control); $\square, 4 ; 0,8 ; \Delta, 16$.

Effect of patulin upon host macromolecular and PsV-F replication. To demonstrate the effects of patulin upon host metabolism, incorporation of ${ }^{14} \mathrm{C}$-precursors into RNA and protein, fungal growth (biomass) and PsV-F synthesis were measured in the presence of various patulin levels. At 4 and $8 \mu \mathrm{g} / \mathrm{mg}$, patulin had no appreciable effect upon RNA and protein synthesis, dry weight accumulation or PsV-F replication (Fig. 3). However, at I6 $\mu \mathrm{g} / \mathrm{mg}$, patulin reduced biomass accumulation by II \%, whereas protein and RNA synthesis were reduced 38 and $20 \%$, respectively, compared with the control culture. PsV-F replication was inhibited $85 \%$ in a $48 \mathrm{~h}$ incubation. Therefore, the patulin level at which inhibition of PsV-F replication is maximal and effects upon host macromolecular machinery minimal, lies somewhere between 8 and $16 \mu \mathrm{g} / \mathrm{mg}$ dry wt biomass.

Effect of patulin upon PSV-S replication. Sub-inhibitory doses of patulin stimulated PsV-S replication during this $48 \mathrm{~h}$ incubation (Fig. 4). Increasing concentrations of patulin enhanced PsV-S replication up to the point where patulin began to inhibit both PsV-F and PsV-S replication. PsV-S levels in mycelium treated with 4 to $16 \mu \mathrm{g} / \mathrm{mg}$ dry wt were enhanced from 3 to 6 times, respectively, compared with untreated cells. However, patulin levels inhibitory to PsV-F replication also blocked PsV-S replication completely. Stimulation of PsV-S by patulin occurred in growing mycelium at concentrations below $12 \mu \mathrm{g} / \mathrm{mg}$ dry wt.

Inhibition of PsV-F replication by patulin in non-proliferating cells of $P$. stoloniferum. The antiviral activity of patulin was evaluated with non-proliferating $P$. stoloniferum mycelium. 


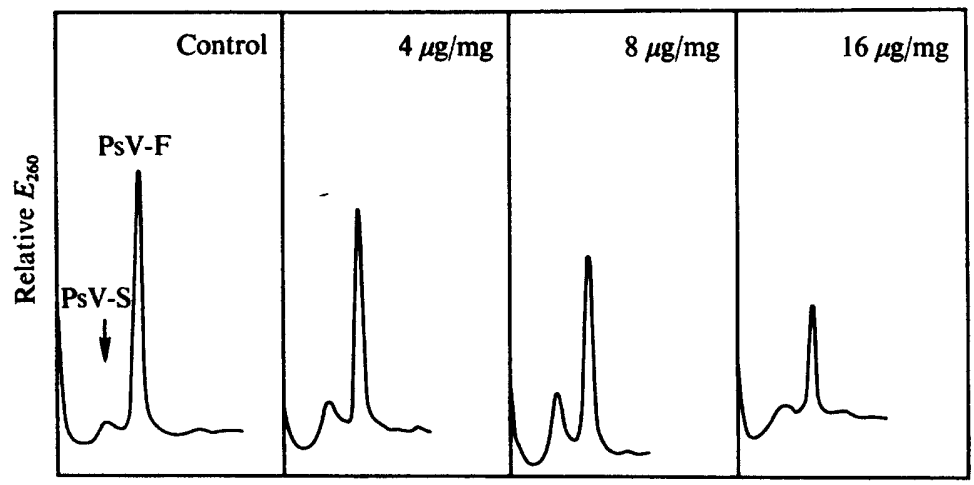

Distance moved $(\mathrm{cm})$

Fig. 4. Electrophoretograms of PsV-F and PsV-S replication in P. stoloniferum in the presence of various levels of patulin. Mycelial portions ( $\mathrm{g}$ get wt) were extracted at $48 \mathrm{~h}$ and analysed for PsV-F and PsV-S content. Equal samples were applied to the gels for comparative analysis.

Table 3. Inhibition of PsV-F replication at varying levels of patulin with non-proliferating cells of $P$. stoloniferum

\begin{tabular}{|c|c|c|c|c|}
\hline \multirow[b]{2}{*}{$\begin{array}{l}\text { Patulin concn* } \\
(\mu \mathrm{g} / \mathrm{mg} \text { dry } w \mathrm{t})\end{array}$} & \multicolumn{2}{|c|}{$24 \mathrm{~h}$} & \multicolumn{2}{|c|}{$48 \mathrm{~h}$} \\
\hline & $\begin{array}{l}\text { Biomass } \\
\text { (g dry wt) }\end{array}$ & $\begin{array}{l}\text { PsV-F } \\
\text { units } \dagger\end{array}$ & $\begin{array}{l}\text { Biomass } \\
\text { (g dry wt) }\end{array}$ & $\begin{array}{l}\text { PsV-F } \\
\text { units } \dagger\end{array}$ \\
\hline Zero time & 0.201 & $3 \cdot 10$ & - & - \\
\hline$\circ$ (control) & 0.191 & $7 \cdot 4 I$ & 0.207 & $10 \cdot 30$ \\
\hline 10 & 0.188 & $7 \cdot 48$ & 0.212 & $9 \cdot 50$ \\
\hline 20 & 0.182 & $6 \cdot 34$ & 0.200 & $9 \cdot 00$ \\
\hline 40 & 0.190 & 6.06 & 0.195 & $7 \cdot 12$ \\
\hline 55 & 0.201 & $5 \cdot 32$ & 0.185 & $5 \cdot 20$ \\
\hline 70 & 0.180 & 3.00 & 0.170 & $2 \cdot 70$ \\
\hline
\end{tabular}

* Patulin was added as 0.1 to $\mathrm{I} \mathrm{ml} \mathrm{solutions} \mathrm{to} 20 \mathrm{ml}$ of $48 \mathrm{~h}$ mycelia of $P$. stoloniferum in $60 \mathrm{ml}$ distilled $\mathrm{H}_{2} \mathrm{O}$ to yield the appropriate ratios. Zero time dry weight was determined before patulin addition.

$\dagger$ Represents $E_{280}$ units of virus as determined by gel electrophoresis.

The $48 \mathrm{~h}$ mycelium was exhaustively washed aseptically with distilled water before resuspending in distilled $\mathrm{H}_{2} \mathrm{O}$, and PsV-F replication was measured after 24 and $48 \mathrm{~h}$ incubation. At $24 \mathrm{~h}, \mathrm{PsV}-\mathrm{F}$ replication was inhibited from 26 to $100 \%$ by patulin at 40 to $70 \mu \mathrm{g} / \mathrm{mg}$ dry wt, and biomass remained unchanged (Table 3). PsV-F replication remained inhibited at $48 \mathrm{~h}$ in the presence of patulin at 40 to $70 \mu \mathrm{g} / \mathrm{mg}$ dry wt. However, biomass decreased slightly at the higher patulin concentrations. The level of inhibition of PsV-F replication was again dependent upon the ratio of patulin to $\mathrm{mg}$ dry wt mycelium.

Since the PsV-F content had increased threefold after a $48 \mathrm{~h}$ incubation, PsV-F replication continued during this $48 \mathrm{~h}$ even though the host was maintained in a non-proliferating state. Therefore, the PsV-F virus must have been utilizing endogenous RNA and protein precursors for synthesis during this $48 \mathrm{~h}$.

\section{DISCUSSION}

The evidence concerning the effects of patulin on biological systems can be classified into primary and secondary effects. Patulin depresses DNA synthesis in HeLa cells, stopping the whole cell cycle (Kawasaki et al. 1972). Other primary effects include blockage 
of RNA and protein syntheses in Chang liver cells (Wilson, 1975) and induction of breaks in HeLa cell DNA after a I h exposure to patulin (Umeda, Yamamoto \& Saito, 1972). The ability of patulin to induce these primary metabolic effects indicates that it may bind directly to host nucleic acid. Patulin binding in vitro to thiol enzymes (Ashoor \& Chu, 1973), inhibition of aerobic respiration of fungi (Singh, 1966) and mammalian cells (Andraud et al. 1963), and induction of petite mutations in Saccharomyces cerevisiae (Mayer \& Legator, 1969) are more secondary. The secondary mode of action of patulin against respiratory enzymes comes from inactivation of enzyme activity and resides in its ability to bind to specific binding sites.

A given biomass of mycelium will contain a certain, finite number of such sites. The same concentration of patulin causes greater inhibition of PsV-F replication in a lower fungal biomass than in a higher biomass (Table I). At the larger biomass, patulin would have access to a greater number of external binding sites. Perhaps all the patulin at the larger fungal biomass is bound to many easily accessible sites, even in the membrane. Membrane components would have little influence on PsV-F replication. At the smaller biomass, patulin has access to fewer membrane binding sites and would leave the remaining unbound patulin available to bind to -sites of internal cellular components important to PsV-F replication.

The binding or possible altering of patulin was complete, because no free patulin was detectable either in the medium or the cell-free supernatants after a $48 \mathrm{~h}$ incubation. At PsV-F inhibitory levels, the patulin may interfere with the synthesis of protein capsid units or viral replicase activity by irreversibly binding to enzymes involved in the formation of complete virus particles.

Resting-cell experiments indicate that continued host-cell protein and RNA synthesis is not required to support PsV-F and PsV-S replication. Although the host was in a nongrowth stationary phase, the two viruses increased threefold, utilizing endogenous precursors and host protein-synthesizing machinery. The washed mycelium showed little or no observable lysis at $48 \mathrm{~h}$ in a resting-cell environment but did support continued viral replication.

Patulin inhibition of PsV-F replication in resting cells may also be a result of saturation binding to active sites on a viral replicase and prevention of ds-RNA synthesis.

The mechanism by which sub-inhibitory levels of patulin induce a stimulation in PsV-S replication is unknown. However, we have observed that high levels of sucrose or glucose can somehow repress PsV-S replication in media with yeast extract and Casamino acids (unpublished results). Patulin may in some fashion relieve PsV-S from this repression.

We thank Drs E. B. Lillehoj and A. Ciegler for the patulin, and Mr D. DeMarini for helpful assistance. P. E. Still was a United States NCR-ARS postdoctorial research associate from 1974 to 1975 .

\section{REFERENCES}

Abraham, E. P. \& Florey, H. W. (1949). Substances produced by fungi Imperfecti and Ascomycetes. In Antibiotics, vol. I, pp. 273-355. Edited by H. W. Florey, E. Chain, N. G. Heatly, M. H. Jennings, A. G. Standards, E. P. Abraham and M. E. Florey. London: Oxford University Press.

Andraud, G., Aublet-Cuvelier, A. M., Covquelet, J., Cuvelier, R. \& Tronche, P. (1963). Activité comparée sur la respiration cellulaire de la patuline naturelle et d'un isomere synthèse. Comptes rendus des séances de la Société de biologie et de ses filiales 157, 1444-1446.

AshoOR, S. H. \& CHU, F. S. (1973). Inhibition of alcohol and lactic dehydrogenases by patulin and penicillic acid in vitro. Food and Cosmetics Toxicology xr, 61 7-624. 
Atxinson, N. \& Stanley, N. F. (1943). Antibacterial substances produced by moulds. The detection and occurrence of suppressors of penicillin activity. Australian Journal of Experimental Biological and Medical Science 2I, 249-253.

Birkinshaw, J. H., Bracken, A. \& Morgan, E. N. (1948). The constitution of mycocephenolic acid. Biochemical Journal 42, 49-50.

BozARTH, R. F. (1972). Mycoviruses: a new dimension in microbiology. Environmental Health Perspective 2, 23-39.

Bozarth, R. F., Wood, H. A. \& MANdelbrot, A. (1971). The Penicillium stoloniferum virus complex: two similar double-stranded RNA virus-like particles in a single cell. Virology 45, 516-523.

Detroy, R. W., Freer, S. N. \& FenNell, D. I. (1973). Relationship between the biosynthesis of virus-like particles and mycophenolic acid in Penicillium stoloniferum and Penicillium brevi-compactum. Canadian Journal of Microbiology 19, 1459-1462.

Detroy, R. W. \& STILL, P. E. (1975). Fungal metabolites and viral replication in Penicillium stoloniferum. In Developments in Industrial Microbiology, vol. 16, pp. 145-15I. Baltimore:Garamond/Pridemark Press.

DiCKENS, F. \& JoNES, H.E. H. (196I). Carcinogenic activity of a series of reactive lactones and related substances. British Journal of Cancer 15, 85-90.

DiCKens, F. \& JoNES, H. E. H. (1965). Further studies on the carcinogenic action of certain lactones and related substances in the rat and mouse. British Journal of Cancer 19, 392-403.

HoOper, I. R., ANDERSON, H. W., Skell, P. \& CARTER, H. E. (I944). The identity of clavacin with patulin. Science, New York 99, 16-17.

JONES, J. B. \& YOUNG, J. M. (1968), Carcinogenicity of lactones. III. The reactions of unsaturated $\gamma$-lactones with L-cysteine. Journal of Medicinal Chemistry Ir, II76.

KAWASAKI, I., OKI, T., UMEDA, M. \& SATTO, M. (1972). Cytotoxic effect of penicillic acid and patulin on Hela cells. Japanese Journal of Experimental Medicine 42, 327-340.

LemKe, P. A. \& NASH, C. H. (1974). Fungal viruses. Bacteriological Reviews 38, 29-56.

LOENING, U. E. (1967). The fractionation of high-molecular-weight ribonucleic acid by polyacrylamide-gel electrophoresis. Biochemical Journal 102, 25 I-257.

MAYER, V. W. \& Legator, M. S. (1969). Production of petite mutants of Saccharomyces cereviseae by patulin. Journal of Agricultural Food Chemistry 17, 454-456.

Norstadt, F. A. \& McCalla, T. M. (1968). Patulin production by Penicillium urticae Bainier in batch culture. Applied Microbiology 17, 193.

SiNGH, J. (1966). Mechanism of antifungal action of patulin. Ph.D. thesis, University of Illinois.

UmedA, M., YAMAmoto, T. \& SArto, M. (1972). DNA-strand breakage of Hela cells induced by several mycotoxins. Japanese Journal of Experimental Medicine 42, 527-535.

WILSON, D. M. (1975). Patulin and penicillic acid. In Advances in Chemistry, ACS Chemical Series. 